\title{
"I have seen the custom of the King of Egypt in our time as well." A study in Comparative Midrash and Commentary
}

\author{
ABRAHAM OFIR SHEMESH (ARIEL UNIVERSITY, ISRAEL)
}

\begin{abstract}
This study discusses three major explanations by medieval biblical commentators for Moses's meeting with Pharaoh by the Nile in the early morning hours prior to the plagues of blood and wild beasts. The exegetical principle underlying these interpretations is the view that some royal practices were shared by rulers of ancient Egypt and by medieval Muslim and Christian European rulers. Ibn Ezra claimed that Pharaoh ventured out to check the level of the water, as customary of Muslim sultans in his own time. Ibn Caspi suggests that Moses was asked to meet Pharaoh by the Nile where he was accustomed to holding a ball game with his escorts. It seems that he refers to a game of polo that was very popular among Mamluk kings. Bechor Shor and Hizkuni claimed that Pharaoh would get up early to go hunting using birds of prey. Hunting with birds was a common professional sport among the nobility in medieval times. French commentators used the life style of European nobility and royalty in medieval times to reach conclusions about ancient Egypt.
\end{abstract}

KEY WORDS: Moses; Pharaoh; Ibn Ezra; Ibn Caspi; Bechor Shor; Hizkuni; Middle Ages.

\section{A INTRODUCTION}

Before the plague of blood, God instructs Moses to meet with Pharaoh, King of Egypt, by the Nile early in the morning (Exod 7:15): "Go to Pharaoh in the morning, as he is going out to the water; wait for him by the river's brink.", The purpose of this meeting is to order Pharaoh to allow the children of Israel Sons of Israel to leave Egypt and to warn him of the harsh plagues that will be inflicted upon him and his people if he shall not do so. A similar place and time are also stated before the plague of wild beasts (Exod 8:20): "Then the LORD said to Moses, 'Rise up early in the morning and wait for Pharaoh, as he goes out to the water."'

* Article submitted: 2/06/2016; final peer review: 25/06/2016; accepted: 11/07/2016. Abraham Ofir Shemesh, "'I have seen the custom of the King of Egypt in our time as well.' Three contemporary medieval interpretations of Exodus 7:15," Old Testament Essays 29/2 (2016): 336-359, doi: http://dx.doi.org/10.17159/23123621/2016/v29n2a8

The citations are according to the Revised Standard Version (RSV). 
Over the historical periods, different and varied explanations were offered as to the location of the meeting and its timing, and some scholars even found a connection between the two. The current study focuses on three medieval commentaries based on contemporary circumstances. The main goal of the research is to analyze these interpretations in light of the historical and cultural context in which they were written. I shall show that the principle underlying these interpretations is the view that some royal practices were shared by kings of ancient Egypt and by medieval Muslim and European rulers.

As a background to the three medieval commentaries, I shall review and discuss some of the typical interpretations of Exod 7:15 and 8:20. The chronological presentation of the commentaries will include early sources (period of the Sages), interpretations in medieval and pre-modern manuscripts $\left(10^{\text {th }}-16^{\text {th }}\right.$ centuries) and several opinions of modern commentators $\left(20^{\text {th }}-21^{\text {st }}\right.$ centuries $)$. The review will indicate two main types of explanations for the location of the meeting and its timing-material needs (bathing, agricultural purposes) and religious aspects (Nile worship and celebrations). It will also demonstrate that the three interpretations were not proposed prior to the Middle Ages.

The three interpretations reflect the manner and life style of Muslim and Christian European rulers. Analysis of the historical evidence will build on many medieval literature genres, such as medical manuscripts, hunting guides, and archaeological findings.

\section{B REVIEW OF SOME TYPICAL INTERPRETATIONS}

In both cases the biblical narrator (Exod 7:15, 8:20) does not state why Pharaoh was at the Nile, unlike Pharaoh's daughter, of whom it is said that she came to the Nile to bathe (Exod 2:5). The encounter at the Nile prior to the plague of blood was not the first time Moses and Aaron met with Pharaoh. They had met him twice previously (Exod 5:1, 7:1), and these previous meetings probably took place at the royal palace. So why did God decide that this meeting would take place at the Nile, rather than at the palace? The initial compelling reason is that preference was given to the place where the plague was to be inflicted, to lend the threatening message greater effectiveness. The Scriptures state explicitly that the plague of blood was inflicted upon the water of the Nile, but with regard to the plague of wild beasts this would depend on the meaning of the plague and its association with the Nile.

Midrash Rabbah on Parshat Va'era, Parasha 11, brings two interpretive suggestions as to the types of animals that took part in the plague of wild beasts: "The Holy One Blessed be He brought upon them a mixed assortment of animals - said R. Yehuda. R. Nechamia said: swarms of hornets or mosqui- 
tos." 2 Assumedly, both opinions in the midrash identify the animals that were to invade the homes of the Egyptians as those affiliated with the vegetation around the Nile-various mammals, some of them carnivores, or mosquitos and hornets that live in the vicinity of water. According to this understanding, the purpose of the plague of wild beasts was to transform the Nile from a beneficial place (used for hunting) to one that is dangerous and threatening.

\section{Early interpretations}

The Babylonian Talmud, in Moed Katan 18a, as well as the biblical translation attributed to Yonatan ben Uziel, ${ }^{3}$ present the claim that Pharaoh was a sorcerer (amgushi) and that he ventured out to the Nile early in the morning for purposes of sorcery. The Old Testament makes no mention of Pharaoh as a sorcerer, but he is cited as taking counsel with his sorcerers and using their magic knowledge (see for example Exod 7:11-12; Exod 7:22; Exod 8:3). According to Targum Pseudo-Jonathan, Jannes and Jambres were Pharaoh's chief sorcerers, and they contended with Moses and Aaron (see Targum Pseudo-Jonathan, Exod $1: 15 ; 7: 11){ }^{4}$

The Jerusalem Translation (also known as the "Fragment Targums" or “Targum Yerushalmi II") and the Targum Neofiti on Exod 7:15 explain that Pharaoh went to the river to cool himself, that is, he would bathe in the river in

2 Exodus Rabbah, Avigdor Shinan Edition (Jerusalem and Tel Aviv: Dvir, 1984), Parshat Va'era, Parasha 11, 240. On the plague in Exod 8:20 as stable fly or dog fly (Stomoxys calcitrans) see also Septuagint (Sir Lancelot C. L. Brenton 1851 edition), Exod 8:21-24; Philo of Alexandria, On the Life of Moses, I, XXIII, 130. On the Greek word $\kappa v v o ́ \mu v i \alpha ~(=\operatorname{dog}$ fly) in these sources, see Henry George Liddell and Robert Scott, "кvvó $\mu v 1 \alpha, " \quad L S J$, http://www.perseus.tufts.edu/hopper/text?doc=Perseus :text:1999.04.0057:entry=kuno/muia. Louis Ginzberg in his book Legends of the Jews describes the plague as "a mixed horde of wild animals, lions, bears, wolves, and panthers, and so many birds of prey of different kinds that the light of the sun and the moon was darkened as they circled through the air." See Louis Ginzberg, Bible Times and Characters from Joseph to the Exodus, vol. 2 of The Legends of the Jews (Philadelphia: The Jewish Publication Society of America, 1913), 343.

3 Translation of Yonatan ben Uziel on the Torah, Moshe Ginzburger Edition (Berlin: Kaloari, 1903), 108. According to the Babylonian Talmud, Yonatan ben Uziel fashioned an Aramaic translation of the Prophets, while it makes no mention of any translation by him of the Torah (see Megillah 3a). The date of the Targum PseudoJonathan composition is disputed. The main opinions on its date are $4^{\text {th }}$ century or $7^{\text {th }}$ 8 th century, and in any case no later than the early $14^{\text {th }}$ century. On this issue see Avigdor Shinan, "Dating Targum Pseudo- Jonathan: Some More Comments," JJS 61 (1990): 57-61.

4 The names of Jannes and Jambres appear also in the New Testament. See 2 Timothy 3:8 (NIV). 
the early morning when the water was cool and pleasant. ${ }^{5}$ We can assume that this interpretation was influenced by the story about Pharaoh's daughter bathing in the Nile (Exod 2:5).

\section{Interpretations in medieval and pre-modern manuscripts}

In Exodus Rabba 1 (chs. 1-10), which according to Shinan was compiled in the $10^{\text {th }}$ century, the exegete offered a polemical interpretation of the encounter at the Nile: "Why did he go out to the river? Because that evil one would praise himself and say that he is a God who does not need to relieve himself, for this reason he would go out in the morning and secretly tend to his bodily needs."

The exegete retells the biblical story in an expanded form, with the new material expressing a new idea through an epic story. ${ }^{7}$ Pharaoh pretended to be a God, of which one manifestation was that he did not have to relieve himself, a physical act that indicates the inferiority of human beings. In order to conceal his human nature from his servants in the royal palace and from his people, he would get up early and relieve himself secretly in the Nile or among the vegetation by the riverside.

The exegete used this intimate embarrassing situation as a means of voicing anti-Egyptian polemics. Pharaoh and the Nile were two major symbols of the ancient Egyptian culture and faith. Pharaoh's relieving himself in the Nile constitutes a debasement of these two cultural icons concurrently. ${ }^{8}$ The aggadic literature of the sages was initiated and generated mostly as a result of its creators' spiritual conflict and contention among themselves (for example, Beit Hillel and Beit Shamai) as well as with foreign beliefs and opinions and other cultures, for example dissident sects such as the Dead Sea Sect, ancient Hellenism, or the foreign and hostile Roman authorities.

5 Tosafot Vechilufin: Jerusalem Translation of the Pentateuch (According to Paris Manuscript), Moshe Ginzburger Edition (Berlin: Calvary 1895), 29; Alejandro Díez Macho, Exodus: Edición Príncipe, Inroducción General y Versión Castellana, vol. 2 of Neophyti 1: Targum Palestinense MS de la Biblioteca Vaticana. (Madrid and Barcelona: Consejo Superior de Investigaciones Científicas, 1970), 3.

6 Exodus Rabbah, Avigdor Shinan edition, Parasha 9, 8, 215. This polemical interpretation appears in other versions that emphasize Pharaoh's embarrassment. See for example Midrash Aggadah, Salomon Buber Edition (Vienna, 1894), Part I, 137: "Moses immediately went and grabbed onto him. He [Pharaoh] said: Let me relieve myself and then I will speak with you. He [Moses] said: Is there a God who has to relieve himself?" And see also Rashi on Exod 7:15 and the sources brought by Menachem Mendel Kasher, Torah Shlema (Jerusalem: Beit Torah Shlema: 1992), Part 9, Parshat Va'era, 39-40, Simanim 57-58. [Hebrew]

7 Yonah Frankel, The Ways of Aggadah and Midrash (Givataim: Yad Latalmud and Masada, 1991), vol. 1, 287-322. [Hebrew]

8 On relieving oneself before an idol as an expression of contempt in Rabbinical literature see b. Abod. Zar. 44b. 
In this context, Egypt and its cultural symbols reflect the ultimate other, and the exegete focuses on Israel's delivery from them as symbolizing their delivery from the foreign culture and faith. Various scholars have raised the possibility that due to the circumstances of Roman occupation and exile surrounding the exegete and his society these Egyptian symbols were enlisted in the service of an agenda that called for removing the burden of the idolatrous Roman culture. ${ }^{9}$ Some claim that this midrash and others are engaged in a debate with the worship of Roman Caesars, through biblical verses that disparage Pharoah and the Egyptian culture. For example, the verse in Ezekiel 23:20 likens the Egyptians to donkeys. A midrash aggadah on Exodus 8:16 portrays Moses as standing before Pharaoh and disparaging the Egyptians who believe him to be a god, while according to the exegete only one who is stupid as a donkey might believe so. ${ }^{10}$

Midrash Lekach Tov, also called Pesikta Zutra, compiled by R. Toviah ben Eliezer in the $11^{\text {th }}$ century, brings additional explanations concerning the time of the encounter. According to one explanation, the reason for meeting in this way was technical: "Since [Pharaoh] would say to Moses: I do not have the time to listen to you, the Holy One Blessed be He said to him: When he goes to the river catch him and confront him, where he cannot avoid you." wanted to meet Pharaoh at his palace, but Pharaoh avoided him, claiming that he had no time to meet. According to another Midrash no one had free access to the monarch. Yalkut Shimoni claims that the Egyptian palace had four hundred entrances, each one of them guarded by beasts of prey, such as lions or bears. ${ }^{12}$ Hence, God advised Moses to initiate an unscheduled meeting, and he revealed to Moses that during the morning Pharaoh leaves the palace.

9 See Avigdor Shinan, The World of the Aggadic Literature (Tel Aviv: Ministry of Defence, 1987), 16. On dealing with the Nile as a polemic platform against the Roman culture see: Rivka Ulmer, Egyptian Cultural Icons in Midrash, Studia Judaica: Forschungen zur Wissenschaft des Judentums 52 (Berlin: Walter de Gruyter, 2009), 41-80; Rivka Ulmer, "The Nile as the Landscape of the Other," in Discussing Cultural Influences: Text, Context, and Non-Text in Rabbinic Judaism, Studies in Judaism, ed. Rivka Ulmer (Lanham: University Press of America, 2007), 193-207.

10 Midrash Aggadah, Salomon Buber Edition (Vienna1894), Part I, 137. See also Ginzberg, Notes to vols I and II, vol. 5 of The Legends of the Jews (Philadelphia 1942), 427, n. 175; Joseph Heinemann, Aggadah and its Development (Jerusalem: Keter Publishing House, 1974), 124-5.

11 R. Toviah ben Eliezer, Midrash Lekach Tov, Slomo Buber Edition (Lvov 1878), 35.

12 See Yalkut Shimoni (Jerusalem, 1960, Facsimile Warsaw 1878), Ex 7: 181. Yalkut Shimoni is compilation of aggadot (midrashim) on all the books of the Bible. The title page of the Venice edition (1566) ascribes the composition of the book to R. Simeon, chief of exegetes of Frankfort. However, the author cannot be determined with 
According to the midrash, at the riverside Pharaoh could not avoid Moses and he was forced to listen to what Moses had to say. According to another explanation offered by the midrash, Pharaoh would go down to the Nile in the early morning hours to "instruct his servants and his people on repairing the Nile." As part of the preparations for the flooding of the Nile, one of Pharaoh's responsibilities was to urge Egyptian farmers to make sure that the canals were in working order so that the water would reach the distant plots and the crops would grow well. ${ }^{13}$ The role and duty of the Egyptian ruler to feed his people is deduced from the story of the seven-year period of drought and famine (Gen 41:48-49). During the seven years of abundance, Joseph collected all the food grown in the fields surrounding the cities and stored up huge quantities of grain.

R. Abraham ben Yaakov Saba (Spain 1440-Italy 1508), who lived at the time of the Spanish Expulsion, claimed that Pharaoh went to the Nile in association with ritual ceremonies held by Egyptian kings at the riverside. He writes:

In the book of royal etiquette, on Egyptian conduct, in the fourth part, it says that Egypt's kings would go to the Nile twice a month - at the beginning of the moon and when it was full - to offer the monthly sacrifices and [Pharaoh] would leave before the sun rose [...] and about this it is written "early in the morning." 14

Celebrations or ritual ceremonies of the Nile were mentioned in Exodus Rabbah ( $5^{\text {th }}$ century) concerning the story of Joseph and Potiphar's wife (Gen 39: 7-23). ${ }^{15}$ According to the midrash, Potiphar's wife attempted to seduce Joseph when Potiphar's household went to the Nile celebrations and they were alone at home. Saba utilizes a tradition he claims to have found in Egyptian writings, whereby the Nile was worshiped as a god or as a fertility ritual to pray for sufficient water. The ritual was conducted by Pharaoh in the early morning, at the beginning and middle of the month (full moon). It makes sense that Moses was instructed to meet Pharaoh during this ritual in order to express the Hebrew God's reservations regarding the divine status awarded to the Nile.

certainty. On this compilation see: Hananel Mack, The Aggadic Midrash Literature (Tel Aviv: Ministry of Defence, 1987), 106-7.

13 Lekach Tov, Ex 7: 28, 36.

14 R. Abraham ben Jacob Saba, Tzror Hamor (Warsaw: Aron Valden, 1879), Parshat Va'era, 13.

15 Exodus Rabbah, Yehudah Theodor and Hanoch Albeck edition (Jerusalem: Wahrmann, 1965), Parasha 87, 1073-1071 


\section{Interpretations of modern commentators}

Some modern commentators disregarded the purpose of Pharaoh's visit to the Nile, apparently because it is not specified in the Scriptures. ${ }^{16}$ Others gave the following explanations: to bow to the Nile that irrigates Egypt, ${ }^{17}$ honoring the Nile particularly at the time of its annual overflow, ${ }^{18}$ to cool off in the water, ${ }^{19}$ a morning excursion or to bathe, ${ }^{20}$ to look at the water for pleasure. ${ }^{21}$ John I. Durham stresses that speculation about the hygienic or religious reasons for Pharaoh's morning visit to the river Nile is not only useless but also a distraction. The substance of the mighty act at hand is the water of the Nile, referred to specifically no less than seven times in twelve verses (Exod 7:14-25). Moses must intercept Pharaoh exactly where the substance for God's mighty act is at hand. Given the nature of the miracle, the place is unavoidable. ${ }^{22}$

\section{MORNING ENCOUNTER AT THE NILE: MEDIEVAL JEWISH INTERPRETATIONS BASED ON CONTEMPORARY REALITY}

\section{R. Abraham Ibn Ezra: Pharaoh went to the Nile to look at the water for health reasons or to check the level of the water}

R. Abraham Ibn Ezra (c. 1090-1164) was born in Toledo, in Muslim Spain. He operated in Spain for the first five decades of his life, and during this period he travelled to different countries in North Africa, such as Tunisia, Morocco, and Algeria. Following the occupation of Al-Andalus by the Murabitun tribes (1090) and then the Al-Mohads (1145), many Jews and Christians, among them Ibn Ezra, were compelled to migrate to Christian countries. For the next three decades he travelled to Christian countries in western Europe - Italy, France, and England - where he utilized the knowledge he had amassed in his youth and adulthood to interpret biblical literature. Ibn Ezra, an intellectual and fertile man of science, engaged in varied fields: biblical commentary, linguistics,

16 Several modern commentators stress that the purpose of Pharaoh's going to the bank of the river is not known, for example Philip J. Hyatt, Commentary on Exodus, NCB (London: Oliphants, 1971), 105; Brevard S. Childs, The Book of Exodus: A Commentary, Old Testament Library (London: SCM Pr., 1974), 122-123.

17 Samuel Leib Gordon, "Exodus," in Bible with a Commentary of Samuel Leib Gordon (Tel Aviv: Masada, 1969), 27. [Hebrew]

18 Hyatt, Commentary on Exodus, 105.

19 William C. Propp, Exodus 1-18, The Anchor Bible (New York: Doubleday, 1999), 323.

20 Moshe David (Umberto) Cassuto, A Commentary on the book of Exodus (Jerusalem: Magnes Press, Hebrew University), 1969, 64 [Hebrew]; Elia Samuele Artom, Tanach, Exodus-Leviticus (Tel Aviv: Yavneh), 1973, 29. [Hebrew]

21 Amos Hacham, Exodus Part 1 (Jerusalem: Mosad Harav Kook, 1991), 114.

22 John I. Durham, Exodus, WBC 3 (Texas: Word Books, 1987), 97. 
philosophy, liturgical poems, mathematics, astronomy and astrology. ${ }^{23}$ His unique intellectual abilities undoubtedly resulted from his personal skills, but they were also enhanced by his life events and his travels to different geographical regions, places, and cultures that enriched his knowledge.

In his biblical commentary, R. Abraham Ibn Ezra occasionally voices the contention that the language, culture, and life style of the Muslim world is capable of contributing to our understanding of contemporary aspects of biblical stories and laws. The material customs and culture of medieval Arabs reflect biblical reality, as the countries of the bible, including the Land of Israel and Egypt, are part of the Arab world. In contrast, Christian countries constitute a different cultural sector, and hence it is not possible to use them to draw conclusions about life in biblical times. ${ }^{24}$

In his commentary on various biblical verses, Ibn Ezra interprets the customs of the kings in biblical times based on those in his own period, although it is not clear from where he derives his knowledge in this area. ${ }^{25}$ Ibn Ezra suggests two interpretations of Pharaoh's visit to the Nile. In his lengthy commentary on Exodus 8:16 he claims that kings venture out to the river in the morning to look at the water for medical reasons: "A custom of the kings is to go to the river in the morning, because looking at the water is good for the

23 Extensive literature exists on how his knowledge in the natural disciplines, as well as in mathematics, astronomy, astrology, and other fields, was utilized for purposes of his biblical commentary, for example: Gad ben Ami Zarfati, Mathematical terminology in Hebrew medieval scientific literature (Jerusalem: Magnes Press, Hebrew University, 1968), 130-155 [Hebrew]; Ezra Z. Melamed, Biblical Commentaries: Their Methods and Approaches (Jerusalem: Magnes Press, Hebrew University, 1978), 628-640 [Hebrew]; Shlomo Sela, Astrology and Biblical Exegesis in the Thought of Abraham Ibn Ezra (Ramat Gan: Bar-Ilan University, 1999), 72-85. [Hebrew]

${ }^{24}$ See, for example, in his lengthy commentary on Exod 12:7. He speaks of the irrelevance of European countries for understanding biblical customs in his lengthy commentary on Exod 28:36, written in 1153 in the city of Daros or Rodus, probably the city Rouen in Normandy, northern France. On Ibn Ezra's view that the reality of life in the Muslim world teaches about the Bible period see also Uriel Simon, The Ear Discerns Words: Studies in Ibn Ezra's Exegetical Methodology (Ramat Gan: Bar Ilan University Press, 2013), 337-339. [Hebrew]

25 See, for example, his commentary on Isaiah 6:1, on the custom to lay "clothes" (=linen) on the chairs of kings; building glass windows in royal palaces (cf. 54:12); the royal habit of getting angry at one's servants (Amos 3:2); and the royal crown embedded with gold and gems (Psalm 21:4). Regarding the custom of showing the queen's beauty before the ministers, Ibn Ezra states explicitly that this is customary among the "kings of Edom," that is, in Christian Europe (Esther 1:11). 
eyes. ${ }^{26}$ He does not state which kings he means, but according to his general outlook whereby the Arab world is a good indication of the conduct of rulers in biblical countries, he probably meant Muslim kings. Muslim medieval palaces were located outside the cities, in green areas with an abundance of water. Their location on the outskirts of the cities was a consequence not only of seeking "fun and pleasure," such as to provide water for the palace gardens or extensive hunting estates, rather first and foremost for economic and political reasons. $^{27}$

In contrast to French-based commentators who claimed that bathing the eyes cures them (see below), according to Ibn Ezra even looking at the water is good for one's health. This stems from a common medical view in the Middle Ages, whereby looking at the light reflecting from the water or from mirrors "illuminates" the eyes. For example, R. Meir ibn Aldabi of Spain (1310-1360) recommends the following to one who suffers from faulty vision: "And one who does not see well [...] should place his face above hot water to receive the smoke [=steam] and should look at clear water."28

In his long commentary on Exodus 7:15 Ibn Ezra applies the principle of understanding ancient times through contemporary reality in a different way. ${ }^{29}$ He suggests that Pharaoh went to the Nile to check the level of the water, as he thought was customary among Egyptian Muslim rulers of his time: "It is the custom of the King of Egypt to this day to go out in the months of Tamuz and Av because that is when the Nile rises, to see how much it has risen." In his short commentary on this site, Ibn Ezra emphasizes that choosing the water level measuring event as a meeting point was intended to publicize the miracle

26 See Abraham Ibn Ezra, Exodus, Long Commentary, vol. 2 of Ibn Ezra: Commentary on the Torah, Asher Veizer edition (Jerusalem: Mosad Harav Kook, 1976), 57.

27 In a separate city the ruler could isolate himself from public opinion and keep his soldiers away from contact with the city. Moreover, the royal villas provided significant revenue for the state and patrons, supplied the court with the luxury crops. On the location of the palaces of the Muslim rulers see: D. Fairchild Ruggles, Gardens, Landscape, and Vision in the Palaces of Islamic Spain (University Park: Penn State University Press, 2000), 53-85; Glaire D. Anderson, "Villa (Munya) Architecture in Umayyad Córdoba: Preliminary Considerations," in Revisiting alAndalus: Perspectives on the Material Culture of Islamic Iberia and Beyond, ed. Glaire D. Anderson and Mariam Rosser-Owen; Brill (Leiden and Boston, 2008), 5379; Madeleine Pelner Cosman and Linda Gale Jones, eds., Handbook to Life in the Medieval World, vol. 1 (New York: Infobase Publishing, 2008), 150.

28 Meir ibn Aldabi, Shvilei Emunah [Paths of Belief] (Warsaw: Zisberg Press, 1874), 30a, and at length Abraham Ofir Shemesh, Medical Materials in Medieval and Modern Jewish Literature: Pharmacology, History and Halacha (Ramat Gan: Bar Ilan University Press, 2013), 456. [Hebrew]

29 Ibn Ezra, Exodus, Long Commentary, 53. 
of the Nile's affliction: "It may have been close to the time that the Nile rises, and the king went out to see this. And God commanded that this wonder be performed in front of Pharaoh when he went there." ${ }^{, 30}$ The choice of this timing probably had two reasons: (i) the public nature of the event and the intention to publicize God's might before all those present at the occasion, and not only the king; (ii) denigration of the Nile as an idolatrous object that inundates life upon Egypt, particularly at the time when the rising water level was being celebrated.

Notably, a similar interpretation to that of Ibn Ezra was brought by Midrash Lekach Tov, compiled several decades earlier by R. Toviah ben Eliezer, who lived and operated in Greece: "As the king goes to the Nile river to see how many steps the water has risen." "It is hard to know whether there is a link between the two commentators and whether this interpretation is based on an earlier source. In any case, the question is, why did the king of Egypt check the water level?

\section{1a The contemporary custom of checking the water level}

In the summer months (from June to September) the water level in the part of the Nile that lay within Egypt's geographical boundaries would rise as a result of the summer rains in the sources of the Blue Nile and White Nile. The water of the Nile is one of Egypt's most important natural resources. Major industries in the ancient Egyptian economy, such as hunting, fishing, and agriculture, were dependent on the Nile. ${ }^{32}$ The flooding season, resulting from the rise in the water level, was crucial for the artificial irrigation of the fields and also for enriching the fields with nutrient-rich silt thanks to the flat plains that bordered the Nile. ${ }^{33}$

R. Toviah ben Eliezer and Ibn Ezra base their interpretation on the custom of measuring the water level in the Nile, customary among Muslim rulers in medieval times. Ibn Ezra indeed never visited Egypt, but he appears to have known about this from external sources. Contemporary sources indicate that the level of the water was usually measured by priests by means of the Nilometer, a column submerged in the water, on which markings were used to determine the depth. Such a device, dated in the early Middle Ages ( $9^{\text {th }}$ century) and housed

30 Ibn Ezra, Exodus, Long Commentary, 253.

31 Midrash Lekach Tov, 8:7, 39.

32 See Shimon F. Bodenheimer, From the Stone Age to the Biblical Period, vol. 1 of Animal Life in Biblical Lands (Jerusalem: Biyalik Institute, 1950), 195. [Hebrew]

33 When the level of the Nile was low or when it dropped in the low season it was necessary to draw the water up, for example with a shaduf (شادوف), a technique that required much effort and labor. On the traditional Egyptian agriculture and irrigation system in the Middle Ages see Stuart J. Borsch, "Nile Floods and the Irrigation System in Fifteenth-Century Egypt," Mamluk Studies Review 4 (2000): 131-45. 
in a stone structure, remains standing on the island of al-Rhoda (الروضة) in central Cairo (see Figure 1). ${ }^{34}$

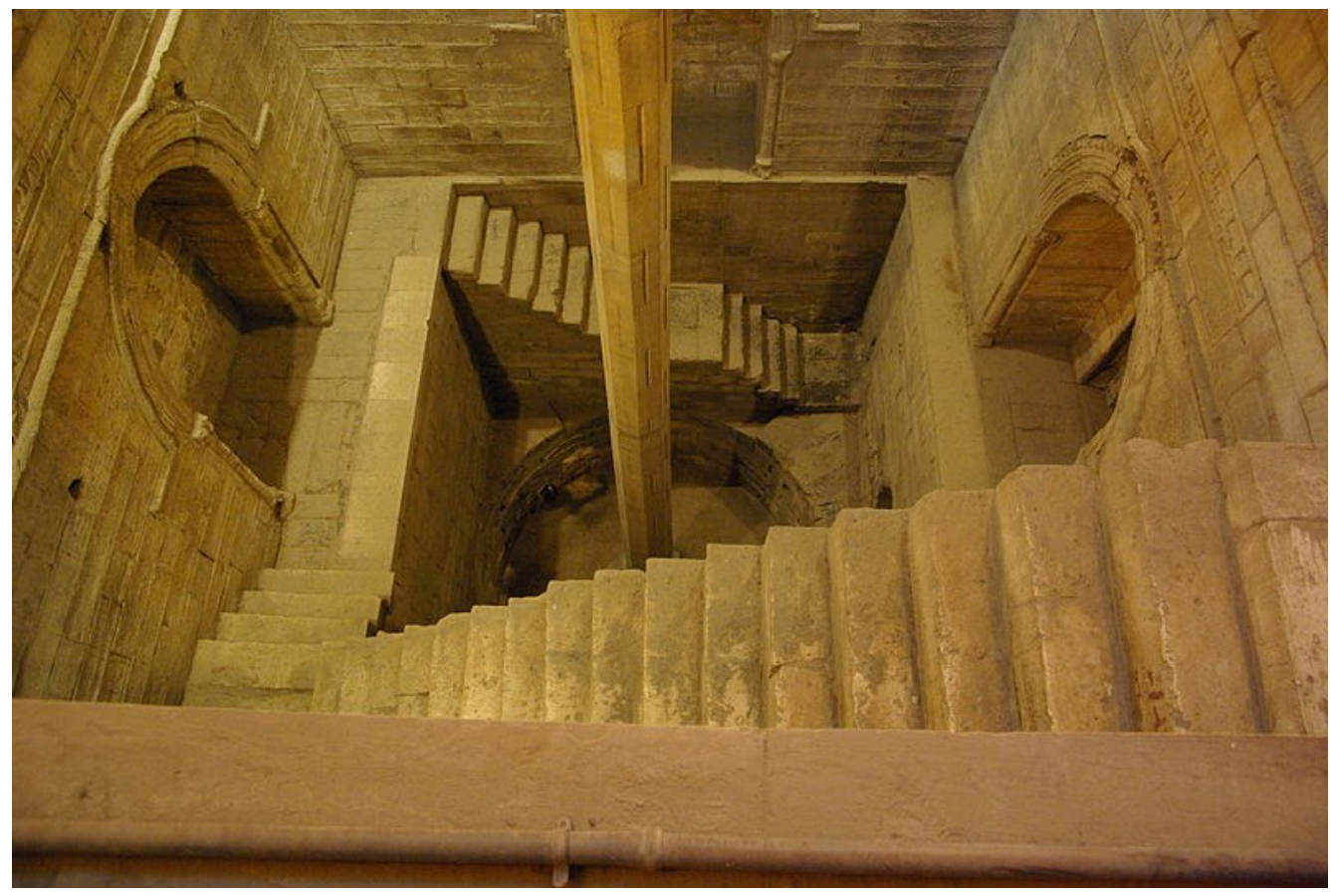

Figure 1: Cairo Nilometer. Image by Berthold Werner (GNU Free Documentation License), https://commons.wikimedia.org/wiki/File:Kairo Nilometer BW 1.jpg). Rights permission is according to Creative Commons (https://creative commons.org/about/) CC BY SA.

When the water would reach a height of 60-80 cubits, that is, 9.3-10.4 m., the agricultural crops were bound to be of good quality. Beginning from the Fatimi period, the "Plenitude of the Nile" was celebrated. During the celebrations, the caliph would approach the Nilometer in a decorated ship and would

34 The construction of the Nilometer on the island of Rhoda is dated in $861 \mathrm{CE}$, commissioned by the Abbasid caliph al-Mutawakkil I (ruler of Samarra from 847861). However it appears to have been built on an earlier device. On the Nilometer of Rhoda in medieval Egypt see Charles C. Torrey, "The Cairo Nilometer: Studies in Ibn Taghrī Birdī's Chronicles of Egypt by William Popper," Speculum 27 (1952): 417-9; K. O. Ghaleb Pacha, Le Miqyâs ou nilomètre de l'île de Rodah, Le Caire: Institut français d'archéologie orientale (IFAO), t. 54, 1951; Heinz Halm, "Die Zeremonien der Sablung des Nilometers und der Kanalöffnung in fatimidischer Zeit," in Egypt and Syria in the Fatimid, Ayyubid and Mamluk Eras. Proceedings of the $1^{\text {st }}, 2^{\text {nd }}$ and $3^{\text {rd }}$ International Colloquium Organised at the Katholieke Universiteit Leuven in May 1992, 1993 and 1994, Orientalia Lovaniensia Analecta 73, ed. Urbain Vermeulen and Daniel De Smet (Louvain: Peeters, 1995), 11-124; Heinz Halm, Die Kalifen von Kairo: Die Fatimiden in Ägypten 973-1074 (München: C.H. Beck Verlag, 2003), 4581. 
perfume it with saffron. ${ }^{35}$ Indications of the merriment that accompanied the rising water are described in the commentary of R. Yehoshua ibn Shuaib (Spain, circa 1280-1340) on Exod 7:15: "And it is already well known and written in the books of the Egyptians that when the Nile would rise the people would gather and have a great festival and they would say: Grow lamb [the Aries zodiac sign], rise Nile, rise Nile." ${ }^{36}$ Ibn Shuaib reports that celebrations of the water's abundance are documented in the literature of Egyptian royalty (compare above to R. Abraham ben Yaakov Saba). In this he alludes to the concept whereby the Egyptians' gratitude for the abundant water was linked to their perception of Aries as affecting the water level.

The act of checking the water level might indicate that Egyptian rulers recognized that the fate of their people and even their own position were dependent on the water sources. A water shortage may have resulted in severe famine, a reduction of taxes on crops, and government instability. In contrast, too much water could lead to destruction of the agricultural canals and to disaster. $^{37}$

\section{R. Yosef ibn Caspi: Pharaoh played ball}

R. Yosef ibn Caspi (Provence, 1279-1340), philosopher, linguist, and biblical commentator, travelled extensively throughout his lifetime, visiting among others Spain, Majorca, and Egypt. ${ }^{38}$ Unlike Ibn Ezra, who as stated never visited Egypt, Ibn Caspi was personally familiar with the Egyptian culture, and as a result he offers an interpretation adapted to his time, based on a custom common among Egyptian kings of the Mamluk period (1250-1517). Ibn Caspi proposes that Moses was asked to meet Pharaoh by the Nile, where he was accustomed to playing ball with his entourage. Ibn Caspi's words are brought in two different versions in his works and I shall compare them. In his work Tirat Kesef (Silver Castle - Interpretation of the Torah's Secrets) he writes:

Notably, the King of Egypt only left his house on Tuesdays and Saturdays, when he would go in the morning to a known spacious area by the Nile to play with a little ball with his horsemen and ministers. And thus it was said: "Confront him on the bank of the Nile", because in my

35 Josef W. Meri and Jere L. Bacharach, eds. Medieval Islamic Civilization, 2 vols (New York: Taylor \& Francis, 2006), 2: 561-562, 273.

36 R. Yehoshua ibn Shuaib, Homilies on the Pentateuch, Shraga Abramson edition (Jerusalem: Makor, 1969 [facsimile edition Cracow 1573]), Parshat Va'era, 23a. [Hebrew]

37 On the role of the Egyptian ruler to see that his people had enough food and water see above, Midrash Lekach Tov. Although the Nile was usually a stable source of water, in certain years its flow was significantly reduced, causing heavy famine in Egypt. See Gen 41:54; Ezek 30:12; Zech 10:11.

38 On the biography of Yosef ibn Caspi see Ephraim Kupfer and Hannah Kasher, "Kaspi, Joseph ben Abba Mari ibn," EncJud 11: 823-825. 
opinion Moses came to him on a small ship on the Nile and spoke to him, as Pharaoh was standing by the riverside, and when he finished speaking he went his way. ${ }^{39}$

In contrast, the following is the version in Matzref Lekesef (Crucible for Silver - Commentary on the Torah):

I have seen the custom of the King of Egypt in our time as well, where two days a week, on the third day and the seventh day, the King of Egypt goes out with his chariot and horsemen, to a designated place by the Nile, to play there all day with a little ball, and maybe Moses could only speak to Pharaoh on those days, because on other days he [Pharaoh] would be in his room [...] Because since Pharaoh would be at the Nile with his netting and tent on those days, Moses could take a small ship and could confront him from the ship. ${ }^{40}$

Ibn Caspi thinks that the reason such a specific time frame was utilized in order to hold the meeting was because normally Pharaoh did not tend to leave his house, aside from the two days a week on which he went out early in the morning to play ball. Without contending with the question of why Pharaoh remained at home, we can try to understand what game this was and whether its description is perhaps anachronistic.

Judging by his description, Ibn Caspi may be referring to the game of polo, which was the most popular ball game in the Arab world in medieval times as it combined two elements to which the Arabs were partial - horses and competitiveness (see Figure 2).

39 R. Yosef ibn Caspi, Tirat Kesef, in Mishneh Kesef, Yitzchak Halevy Last Edition [The First Pamphlet], Perrysburg 1905, Facsimilia, Jerusalem 1970), 19.

40 R. Yosef ibn Caspi, Matzref Lekesef [Commentary on the Torah], in Mishneh Kesef, Yitzchak Halevy Last Edition [The Second Pamphlet, Krakow 1906, Facsimilia, Jerusalem 1970), 155. 


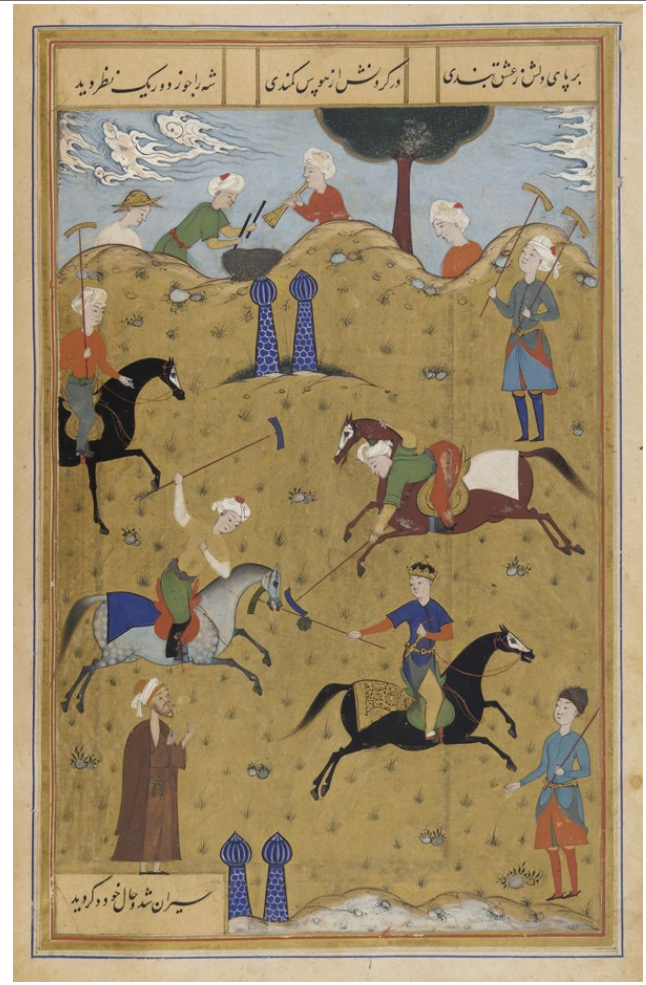

Figure 2: Persian courtiers on horseback playing a game of polo, 1546 AD. From "The poem Guy-o Chawgân of Arifi (d.1449)," Safavid dynasty. https://commons. wikimedia.org/wiki/File:Polo game from poem_Guy u Chawgan.jpg. Rights permission is according to Creative Commons (https://creative commons.org/about/ ) CC BY SA.

The game was played by kings and noblemen, who had the capacity to keep horses, and it also required riding skills, as did hunting and fighting. The game also required saddles and stir-ups, which did not exist in Moses's time. ${ }^{41}$ According to medieval custom, the game was played on horseback. Competitors were divided into two groups and they held a long stick with a crooked end. Each of the groups would endeavor to insert a small ball made of leather or sometimes silver into the goal, which consisted of two posts stationed at some distance from each other. ${ }^{42}$

The game of polo was very popular among the Mamluk elite, as they believed that it helped maintain the combative skills of both riders and horses. Baibars (who died in 1277), the Mamluk sultan of Egypt and Syria, is a good example of a king who encouraged the game of polo in Egypt and even initi-

41 On the polo game in the medieval Islamic world, see Kirk H. Beetz, "Sports and Recreation in the Medieval Islamic World," Encyclopedia of Society and Culture in the Medieval World, Facts On File, http://www.fofweb.com/activelink2.asp? ItemID =WE49\&iPin=ESCMW545\&SingleRecord=True; Josef W. Meri ed., Medieval Islamic Civilization: An Encyclopedia, (New York and London: Routledge, 2006), 1:768-9.

42 Meri, Medieval Islamic Civilization, 768-9. 
ated competitions with representatives of other nations. ${ }^{43}$ James Waterson states that when Baibars was in Damascus or Egypt he would play polo twice a week. This historical detail is compatible with Ibn Caspi's statement that the kings of Egypt played ball twice a week, on Tuesdays and Saturdays. ${ }^{44}$ Ibn Caspi indeed visited Egypt several decades after the death of Baibars, but he may have heard of this custom and maybe it was also common among subsequent sultans.

The historians are conflicted as to the origins of the game. Some claim that it came from Iran, sometime between the $5^{\text {th }}$ century BCE and the $1^{\text {st }}$ century CE. In any case, the Muslims learned it from the Sasanians, and during the Middle Ages it became customary in Egypt as well. ${ }^{45}$ Hence, Ibn Caspi's suggestion is clearly historically untenable as he is applying a relatively late custom to the ancient Egyptians.

It is evident that Ibn Caspi is referring to the game of polo as several details in his description are compatible with the actual game:

(i) Ibn Caspi speaks (in the first version) of a game that takes place in a spacious area, namely, this is not only a game of catch, rather a more intensive game that requires a relatively large playing field.

(ii) The game involves a "little ball" (in both versions), as typical of polo. According to the second version, the game is played "all day," that is, for a lengthy span of time.

(iii) According to both versions, Pharaoh would play the game with his "horsemen." The term "horsemen" in this context refers to people who ride horses in contrast to those who ride in chariots, and this detail as well is compatible with the game of polo.

(iv) Ibn Caspi claims that Pharaoh was by the riverside and Moses was to come to the place of meeting in a "small ship." This detail as well is taken from the Egyptian world where different types of boats were used, made of various materials and sizes. ${ }^{46}$ According to the second version Pharaoh would be standing next to a tent or netting (protection against insects and pests that normally

43 On the polo game in the Mamluks period, see Meri, Medieval Islamic Civilization, 769 .

44 James Waterson, Sacred Swords: Jihad in the Holy Land, 1097-1291 (London: Frontline Books, 2010), 75.

45 Beetz, "Sports and Recreation", http://www.fofweb.com/activelink2.asp?ItemID $=$ WE49\&iPin=ESCMW545\&SingleRecord=True; Meri, Medieval Islamic Civilization, 768-769.

46 On the boats in the Nile in the $16^{\text {th }}$ century see Pierre Belon, Le Voyage en Egypte de Pierre Belon du Mans 1547 (Le Caire: Institut français d'archéologie orientale, 1970), 101a-b. 
thrive in the vicinity of water) located "on the banks of the Nile," namely on the edge of the playing field. Moses was to speak with him from the boat and then go on his way. Moses probably could not disembark because polo is a game played on horseback and it is dangerous for people to be on the field while it is being played.

\section{French sages: Pharaoh went for a walk or to hunt in the bushes along the Nile}

Biblical commentators from among the French Tosafits explained that Moses was supposed to have met Pharaoh who was in the middle or beginning of a hunting trip in the Nile area with its many mammals and waterfowl. R. Yosef ben R. Yitzhak from Orleans, nicknamed "Bechor Shor" $\left(12^{\text {th }}\right.$ century) writes:

It is the practice of ministers and kings to tarry by the riverside, and they bring birds in their hands, such as astor and esparvieres ${ }^{47}$ and take [=hunt] other birds with them, called divarre [riveiere?], and that is where you should speak with him. ${ }^{48}$

A similar interpretation is that of $\mathrm{R}$. Hezekiah ben Manoah Hizkuni (1250-1310), who was influenced by the interpretations of previous French sages: ${ }^{49}$

As he goes out to the river' [...] as is customary among people who get up early by the riverside and bathe in the river to illuminate their eye[s] [=to waken themselves or for medical reasons]. ${ }^{50}$ Another thing, "as he goes out to the river" - for an excursion and to hunt fowl with a hawk

47 ostira is probably the current-day Northern goshawk (Accipiter gentilis, in Arabic: Baz, بَأْ $)$. The esprevrish is apparently to be identified with the Eurasian sparrowhawk (Accipiter nisus).

48 Yeoshafat Nevo, The Commentaries of $R$. Josef Bechor Shor to the Torah (Jerusalem: Mosad Harav Kook, 1993), Exod 7:15. On R. Josef Bechor Shor see Ephraim E. Urbach, Ba'ale Hatosafot: Their Generations, Their Works, Their Methods (Jerusalem: Biyalik Institute, 1986), 132-142 [Hebrew]; Yehoshafat Nevo, "The exegetical method of R. Joseph Bekhor Shor" (D.Lit. et Phil., University of Leiden), 1987.

49 On the story of his life and on the sages that influenced Hizkuni's commentaries see Chaim D. Chavel, The Commentaries of Hizkuni on the Tora (Jerusalem: Mosad Harav Kook, 1981), 6; Sara Japhet, "Hizkuni's commentary on the Pentateuch - on the nature of the compilation and its purpose," in Jubilee Volume in honor of Mordechai Breuer: Articles in Jewish Studies, ed. Moshe Bar-Asher (Jerusalem: Akademon, Hebrew University, 1992), 1: 91-112. [Hebrew] On the link between the commentary of Hizkuni and the Bechor Shor see: Yeoshafat Nevo, "Attitude of Hizkuni, commentator on the Pentateuch, to the commentary of R. Yosef Bechor Shor," Sinai 91 (1982): 17-22. [in Hebrew]

50 Washing one's eyes in the morning was perceived by the ancients as very beneficial for their health. See b. Shabbat 108 b. 
(originally getz, should be netz) that he carries on his arm as kings are wont to do, and that's where you will find him free to talk. ${ }^{51}$

These two interpretations describe a method of hunting by using birds of prey, called "falconry" or "hawking." This method is also mentioned in the interpretations of French sages on the contents of the gift that Jacob sent Esau (Gen. 32:14). R. Ephraim bar Yitzhak of Regensburg (Rabbenu Ephraim, 11101175) writes:

I have heard in the name of the Gaon Rabbenu Tam of blessed memory: "And from what he had with him (literally: from what he had in his hand) he selected"- -from what people are wont to carry on their hand, and that is the hawk, called astor, which kings and ministers carry on their arm to hunt fowl, and it is very important to them, because with it they can hunt without laying a trap, and Jacob knew that Esau his brother was a man of the field and a hunter, so this was the gift he chose to give him. ${ }^{52}$

According to the biblical list, the animals given to Esau as a gift included farm animals, such as goats, camels, bulls, and she-asses, but not birds (Gen 32:1416). According to Rabbenu Tam, who is said to have engaged in falconry himself (see note below), birds of prey would have made a nice gift for Esau, who was an expert hunter (compare: "a skillful hunter, a man of the open country," Gen. 25:27). These birds are used as a unique hunting technique favored by hunters, and hence were a creative way of getting on Esau's good side and complimenting him. Obviously, this interpretation too is based on circumstances in medieval France, where hunting with birds of prey was a sport typical of the nobility.

The interpretations of Bechor Shor, Hizkuni, and R. Ephraim share several factual foundations that must be elaborated: (i) The role of falconry among

51 Chavel, The Commentaries of Hizkuni, 199. Dov Chavel states that the word getz appears in the Oxford Bodleian manuscript no. 568, and he had difficulty understanding its meaning. This is probably a disruption as a result of confusing the letter nun for gimel and it should be netz (=hawk), a bird of prey used for hunting.

52 Jacob Gellis, Tosafot Hashalem (Jerusalem: Mifal Tosafot Hashalem, 1984), III: 215, section 6. The words are also attributed to Rabbenu Tam in the Moscow Ginsburg manuscript, 122a: “"And from what he had with him'-I have heard in the name of the Gaon Rabbenu Tam of blessed memory that this was from what people are wont to bring on their hand, and that is the hawk, which kings and ministers bring on their arm to hunt fowl, and it is very important." However in the Oxford BodleyBodleian, manuscript no. 270 and in the Vatican manuscript no. 48, as well as in other versions, the tradition is not attributed to Rabbenu Tam and the fowl used for hunting is also different - esparviere, i.e., a Eurasian sparrowhawk. The interpretation offered by the French sages appears later on in Spain, albeit anonymously, cited by Rabbenu Bechaye who lived in Saragossa (1255-1340). See Rabbenu Bechaye ben Asher ibn Halawa, Rabbenu Bechaye: Commentary on the Tora (Warsaw: Bomberg 1852), 98a. 
medieval European nobility and its implications for biblical commentators; (ii) The birds used for purposes of falconry and how they were carried to the hunting field.

\section{3a Hunting with birds of prey in medieval times: The actual circumstances underlying the interpretation suggested by French sages}

Hunting with birds of prey evolved in ancient times in the region between central Asia and the Middle East. It began as a means of obtaining food, and was later used by kings and the nobility for fun and entertainment. ${ }^{53}$ The art of falconry was part of the education of European knights and aristocrats, who took pride in the hunting bird on their arm as they did in the sword on their hip. ${ }^{54}$ Falconry became a professional field among European nobility only after the Crusades. This development should be attributed to the publication of famed guide published by Friedrich II (1194-1250) in the 1240s, De arte venandi cum avibus (figure 3 ). ${ }^{55}$

53 Hunting with birds of prey or using birds as bait was known in biblical countries, for example among the Hittites and the Egyptians. See J. Vorys Canby, "Falconry (hawking) in Hittite lands," Journal of Near Eastern Studies 61 (2002): 161-201. On the types of birds of prey used for falconry in the ancient world see Edward Blair Mitchell, The Art and Practice of Hawking (London: Methuen, 1900), 9-39; Canby, "Falconry," 161-3.

54 On the Falconry in ancient times see Hans J. Epstein, "The Origin and Earliest History of Falconry," Isis 34 (1943): 497-509. On the role of hunting as a sport among European aristocracy in medieval times see William H. Forsyth, "The Noblest of Sports: Falconry in the Middle Ages," The Metropolitan Museum of Art Bulletin 2 (1944): 253-259. The Muslim-Syrian knight Usāmah ibn Murshid ibn 'Alī ibn Munqidh al-Kināni al-Kalbi (1095-1188), whose book Kitab al-I'tibar (كتاب الاعتبار) on hunting was very popular in the western world, describes the capture of the falcons, their training, and the types of hunting that were common in medieval times, in his fourth part called "Hunting stories." See Usamah ibn-Munqidh An Arab-Syrian Gentleman and warrior in the period of the Crusades: Memoirs of Usamah ibnMunqidh (Kitab al-I'tibar), trans. Philip Khuri Hitti (New York: Columbia University, 2000), 222, 232, 253.

55 S. F. Bodenheimer, From the Second Temple Period to the End of the Nineteenth Century, vol. 2 of Animal Life in Biblical Lands, (Jerusalem: Biyalik Institute, 1957), 192-193. On the hunting guide published by Friedrich II, see Charles H. Haskins, "The 'De Arte Venandi cum Avibus' of the Emperor Frederick II," The English Historical Review 36 (1921): 334-355; Casey A. Wood and Florence M. Fyfe, trans. and eds., The Art of Falconry by Friedrich II of Hohenstaufen (California: Stanford University Press 1961), XXXV-XCV. 


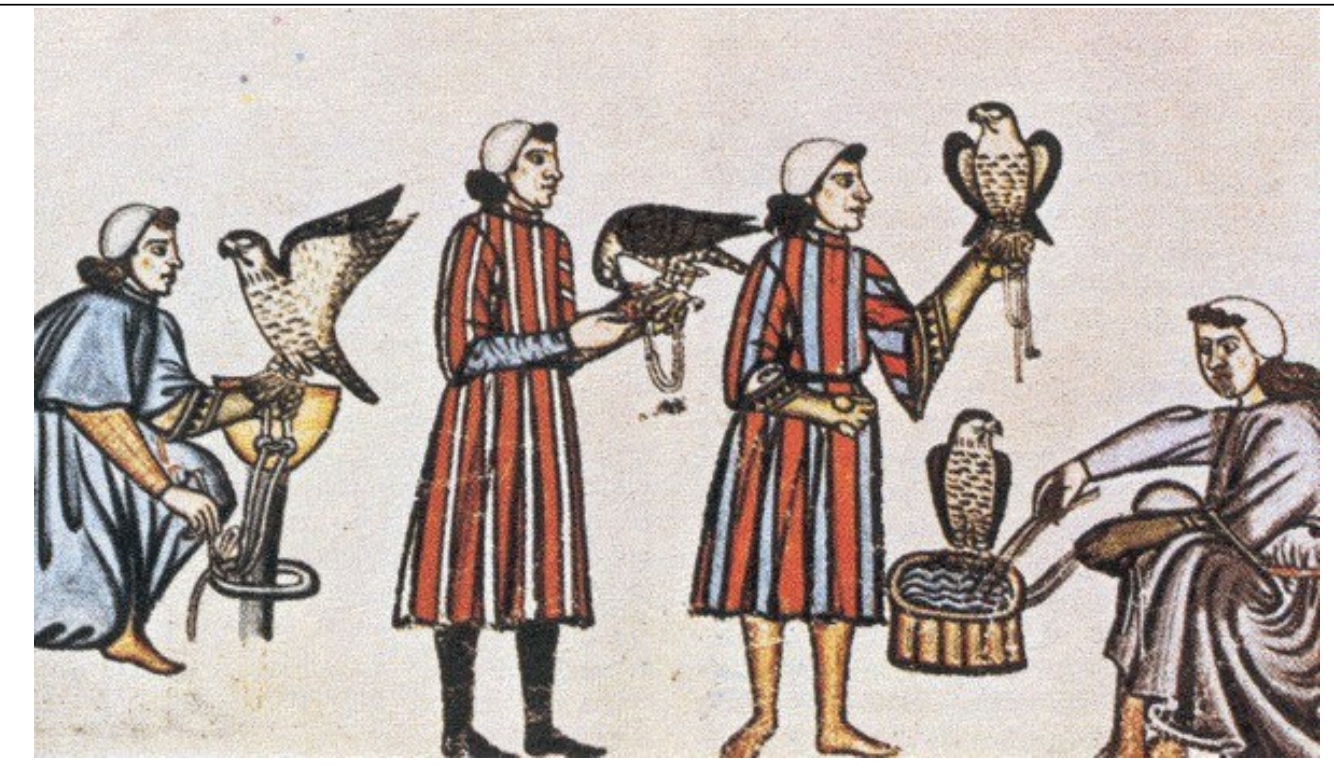

Figure 3: Hunters with falcons before leaving for the hunt. The bird of prey is held on one's hand. From: De arte venandi cum avibus (Biblioteca Apostolica Vaticana, Ms.Lat. 1071), ca. 1250. https://commons.wikimedia.org/ wiki/File:De arte venandi cum avibus3.jpg. Rights permission is according to Creative Commons (https://creativecommons.org/about/). CC BY SA

Hizkuni appears to be describing falconry when this art was in the process of expansion among French aristocratic circles. Bechor Shor and Hizkuni ascribe to Pharaoh an interest in falconry, as common among the royalty in their own time. Moses's meeting with Pharaoh at this specific timing emphasizes the disparity between Moses, a member of the inferior class of slaves who do not engage in this type of hunting, and the king for whom falconry is emblematic of his high social status (Figure 4).

Hunting was a group activity - the nobleman, his friends, and their assistants. The hunters rode horses and were accompanied by hunting dogs who pursued prey on the ground or fetched birds that had fallen at a distance (see at the bottom of the picture). In this case birds are being hunted, and the bird of prey is indeed pursuing them. The figure on the left is carrying the bird of prey on the back of the palm, while the figure on the right has already released the bird of prey to catch the bird in the upper part of the picture.

\section{CONCLUSION}

This article discusses three major explanations by medieval biblical commentators for Moses's meeting with Pharaoh by the Nile in the early morning hours prior to the plagues of blood and wild beasts. These interpretations were not mentioned in the Talmud or in the early Midrash, and they have in common their foundation in current-day medieval reality. The exegetical principle underlying these interpretations is the view that some royal 


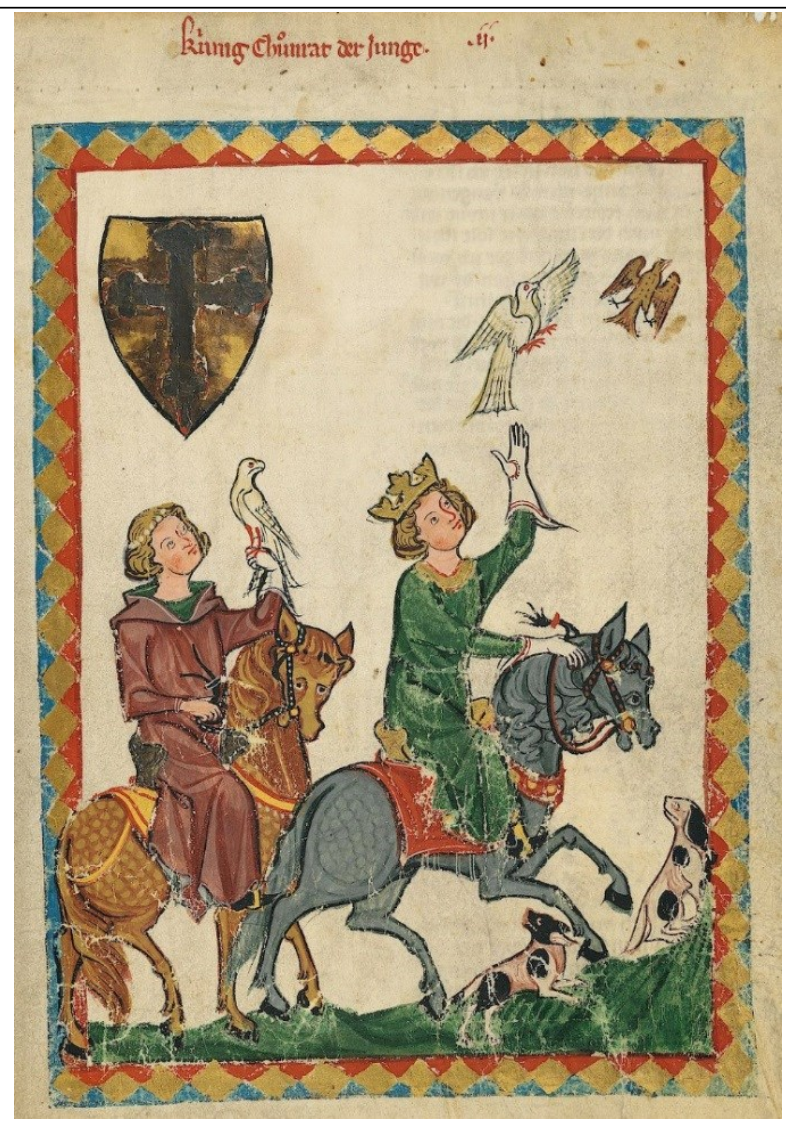

Figure 4: King Conrad the Younger hawking. From: The Codex Manesse (Folio 7r), 14th century https://commons.wikimedia.org/wiki/File:Konradin.jpg and http://digi.ub.uni-heidelberg.de/diglit/cpg848/0009; doi: 10.11588/diglit.2222\#0009. (Rights permission is according to Creative Commons (https:// creativecommons.org/about/) CC BY SA.

practices were shared by rulers of ancient Egypt and by medieval Muslim and Christian European rulers. Nonetheless, it is clear that distant diverse periods are not comparable and that historical continuity is not always maintained.

The tendency to copy later contemporary circumstances to biblical times is also evident in rabbinical literature describing the forefathers of the nation and biblical figures based on their own reality. One example of this is the Midrash that tells of Pharaoh who goes to the Nile to relieve himself, alluding to the worship of Roman Caesars. Isaac Heinemann, who called this phenomenon "bringing the distant near" or anachronism, claimed that interpretation of the Bible in terms taken from the exegete's time was intended to create a sense of continuity between the biblical world and the theological world of the sages. The Bible and the aggadah are distinguished not only by their times but also by their different cultural worlds. In order to make the Bible relevant for the events of Hellenistic and Roman periods, the sages interpreted it according to 
their times. ${ }^{56}$ In fact, medieval interpretation as well tried to give biblical events new meaning that would be relevant for contemporary times, for example by citing royal customs in Christian Europe and in Muslim countries.

In Fatimid, Ayyubid, and Mamluk Egypt, the level of the Nile was measured with a Nilometer. Ibn Ezra had never been to Egypt but he must have heard about this custom and therefore claimed that Pharaoh ventured out to check the level of the water, as customary in Ibn Ezra's own time. However, the information about this custom is from the early Middle Ages and nothing can be deduced from this about ancient Egypt. Ibn Caspi who, in contrast to Ibn Ezra did visit Egypt, suggests that Moses was asked to meet Pharaoh by the Nile where he was accustomed to holding a ball game with his escorts. Based on the data he provides, he appears to be alluding to the game of polo that was very popular among Mamluk kings. But this interpretation is anachronistic and illogical, as the game is only known from much later periods.

The Bechor Shor and the Hizkuni, who lived and operated in France in the $12^{\text {th }}$ and $13^{\text {th }}$ centuries, claimed that Pharaoh would get up early to go hunting using birds of prey. Hunting with birds was customary in Eastern countries even before medieval times. In Europe it became a common professional sport among the nobility only after the Crusades. French commentators used the life style of European nobility and royalty in medieval times to reach conclusions about ancient Egypt. Members of the higher classes in these countries spent their free time hunting animals, and these commentators recognized in Pharaoh a similar pattern to that familiar to them.

\section{BIBLIOGRAPHY}

Anderson, Glaire D. "Villa (Munya) Architecture in Umayyad Córdoba: Preliminary Considerations." Pages 53-79 in Revisiting al-Andalus: Perspectives on the Material Culture of Islamic Iberia and Beyond. Edited by Glaire D. Anderson and Mariam Rosser-Owen. Brill: Leiden and Boston, 2008.

Artom, Elia Samuele. Tanach, Exodus-Leviticus. Tel Aviv: Yavneh, 1973. [Hebrew]

Beetz, Kirk H. "Sports and Recreation in the Medieval Islamic World," No Pages in Encyclopedia of Society and Culture in the Medieval World: Ancient and Medieval History Online. Edited by Pam J. Crabtree. New York: Facts On File, Inc., 2008. http://www.fofweb.com/activelink2.asp?ItemID=WE49\&iPin $=$ ESCMW545\&SingleRecord=True.

Belon, Pierre. Le Voyage en Egypte de Pierre Belon du Mans 1547. Le Caire: Institut français d'archéologie orientale, 1970.

Ben Ami Zarfati, Gad. Mathematical terminology in Hebrew medieval scientific literature. Jerusalem: Magnes Press, Hebrew University, 1968. [Hebrew]

56 See Itzhak Heinemann, The Ways of the Aggadah (Jerusalem: Magnes Press, 1954), 35-39 [Hebrew]; Heinemann, Aggadah and its Development, 9-10; Elimelech A. Halevi, The Gates of the Aggadah (Tel Aviv: The Author, 1982), 5-6. [Hebrew] 
Ben Asher ibn Halawa, Rabbenu Bechaye: Commentary on the Tora. Warsaw:

Bomberg 1852. [Hebrew]

Ben Eliezer, Toviah. Midrash Lekach Tov. Lvov: Slomo Buber Edition, 1878.

[Hebrew]

Ben Jacob Saba, Abraham. Tzror Hamor. Warsaw: Aron Valden, 1879. [Hebrew]

Bodenheimer, Shimon. F. Animal Life in Biblical Lands, 2 vols. Jerusalem: Biyalik Institute, 1950-1957. [Hebrew]

Borsch, Stuart J. "Nile Floods and the Irrigation System in Fifteenth-Century Egypt." Mamluk Studies Review 4 (2000): 131-45.

Canby, Jeanny V. "Falconry (hawking) in Hittite lands." Journal of Near Eastern Studies 61 (2002): 161-201.

Cassuto, Moshe D. (Umberto). A Commentary on the Book of Exodus. Jerusalem: Magnes Press and Hebrew University, 1969. [Hebrew]

Chavel, Chaim D. The Commentaries of Hizkuni on the Tora. Jerusalem: Mosad Harav Kook, 1981. [Hebrew]

Childs, Brevard S. The Book of Exodus: A Commentary. Old Testament Library. London: SCM Pr., 1974.

Cosman, Madeleine Pelner and Linda Gale Jones, eds. Handbook to Life in the Medieval World. New York: Infobase Publishing, 2008.

Díez Macho, Alejandro. Exodus: Edición Príncipe, Inroducción General y Versión Castellana, vol. 2 of Neophyti 1: Targum Palestinense MS de la Biblioteca Vaticana. Madrid and Barcelona: Consejo Superior de Investigaciones Científicas, 1970.

Durham, John I. Exodus. Word Biblical Commentary 3. Texas: Word Books, 1987. Epstein, Hans J. "The Origin and Earliest History of Falconry.” Isis 34 (1943): $497-$ 509.

Exodus Rabbah. Avigdor Shinan Edition. Jerusalem and Tel Aviv: Dvir, 1984. [Hebrew]

Exodus Rabbah. Yehudah Theodor and Hanoch Albeck Edition. Jerusalem: Wahrmann, 1965. [Hebrew]

Forsyth, William H. "The Noblest of Sports: Falconry in the Middle Ages." The Metropolitan Museum of Art Bulletin 2 (1944): 253-259.

Frankel, Yonah. The Ways of Aggadah and Midrash. Givataim: Yad Latalmud and Masada, 1991. [Hebrew]

Gellis, Jacob. Tosafot Hashalem. Jerusalem: Mifal Tosafot Hashalem, 1984. [Hebrew]

Ghaleb Pacha, K.O. Le Miqyâs ou nilomètre de l'île de Rodah, Le Caire, Institut français d'archéologie orientale IFAO, t. 54, 1951.

Ginzberg, Louis. The Legends of the Jews. 5 vols. Philadelphia: The Jewish Publication Society of America, 1913-1942.

Gordon, Samuel Leib. Bible with a Commentary of Samuel Leib Gordon. Tel Aviv: Masada, 1969. [Hebrew]

Hacham, Amos. Exodus. Jerusalem: Mosad Harav Kook, 1991. [Hebrew]

Halevi, Elimelech A. The Gates of the Aggadah. Tel Aviv: The Author, 1982. [Hebrew]

Halm, Heinz. "Die Zeremonien der Sablung des Nilometers und der Kanalöffnung in fatimidischer Zeit." Pages 11-124 in Egypt and Syria in the Fatimid, Ayyubid and Mamluk Eras, Proceedings of the 1st, 2nd and 3rd International Colloquium Organised at the Katholieke Universiteit Leuven in May 1992, 1993 
and 1994. Orientalia Lovaniensia Analecta 73. Edited by Urbain Vermeulen and Daniel De Smet. Louvain: Peeters, 1995.

. Die Kalifen von Kairo: Die Fatimiden in Ägypten 973-1074. München:

C.H. Beck Verlag, 2003.

Haskins, Charles H. 'The 'De Arte Venandi cum Avibus' of the Emperor Frederick

II." The English Historical Review 36 (1921): 334-355.

Heinemann, Joseph. Aggadah and its Development. Jerusalem: Keter Pulishing House, 1974. [Hebrew]

Heinemann, Itzhak. The Ways of the Aggadah. Jerusalem: Magnes Press, 1954. [Hebrew]

Hyatt, Philip J. Commentary on Exodus. New Century Bible. London: Oliphants, 1971.

Ibn Aldabi, Meir. Shvilei Emunah. Warsaw: Zisberg Press, 1874. [Hebrew]

Ibn Caspi, Yosef. Matzref Lekesef [Commentary on the Torah] in Mishneh Kesef, Yitzchak Halevy Last Edition [The Second Pamphlet]. Jerusalem 1970 (Facsimilia Krakow 1906). [Hebrew]

Ibn Caspi, Yosef. Tirat Kesef in Mishneh Kesef, Yitzchak Halevy Last Edition [The First Pamphlet]. Jerusalem 1970 (Facsimilia Perrysburg 1905). [Hebrew]

Ibn Ezra, Abraham. Exodus, Long Commentary. Vol. 2 of Ibn Ezra: Commentary on the Torah. Asher Veizer Edition. Jerusalem: Mosad Harav Kook, 1976. [Hebrew]

Ibn Shuaib, Yehoshua. Homilies on the Pentateuch. Shraga Abramson edition. Jerusalem: Makor, 1969 (Facsimile edition Cracow 1573). [Hebrew]

Ibn-Munqidh, Usamah. An Arab-Syrian Gentleman and warrior in the period of the Crusades: Memoirs of Usamah ibn-Munqidh (Kitab al-I'tibar). Translated by Philip Khuri Hitti. New York: Columbia University, 2000.

Japhet, Sara. "Hizkuni's commentary on the Pentateuch - on the nature of the compilation and its purpose." Pages 91-112 in vol. 1 of Jubilee Volume in honor of Mordechai Breuer: Articles in Jewish Studies. Edited by Moshe Bar-Asher, Jerusalem: Akademon, Hebrew University, 1992. [Hebrew]

Kasher, Menachem M. Torah Shlema. Jerusalem: Beit Torah Shlema, 1992. [Hebrew]

Kupfer, Ephraim and Kasher, Hannah. "Kaspi, Joseph ben Abba Mari ibn." Pages 823-825 in vol. 11 of Encyclopedia Judaica, $2^{\text {nd }}$ ed. Edited by Michael Berenbaum and Fred Skolnik. Detroit: Macmillan Reference USA, 2007.

Liddell, Henry G. and Scott, Robert. A Greek-English Lexicon revised and augmented throughout by Sir Henry Stuart Jones (with the assistance of Roderick McKenzie). Oxford: Clarendon Press 1940. http://www.perseus. tufts.edu/hopper/text?doc=Perseus:text:1999.04.0057:entry=kuno/muia.

Mack, Hananel. The Aggadic Midrash Literature. Tel Aviv: Ministry of Defence, 1987.

Melamed, Ezra Z. Biblical Commentaries: Their Methods and Approaches. Jerusalem: Magnes Press, Hebrew University 1978. [Hebrew]

Meri, Josef W. and Jere L. Bacharach, Medieval Islamic Civilization. New York: Taylor \& Francis, 2006.

Meri, Josef W. Medieval Islamic Civilization: An Encyclopedia. New York and London: Routledge, 2006.

Midrash Aggadah. Salomon Buber Edition. Vienna, 1894. [Hebrew]

Mitchell, Edward B. The Art and Practice of Hawking. London: Methuen, 1900. 
Nevo, Yehoshafat. “The Exegetical Method of R. Joseph Bekhor Shor,” D.Lit. et Phil., University of Leiden, 1987. "Attitude of Hizkuni, Commentator on the Pentateuch, to the

Commentary of R. Yosef Bechor Shor." Sinai 91 (1982): 17-22. [Hebrew] . The Commentaries of R. Josef Bechor Shor to the Torah. Jerusalem:

Mosad Harav Kook, 1993. [Hebrew]

Philo, On the Life of Moses. Translated by Charles Duke Yonge. London: H. G. Bohn, 1854-1890.

Propp, William C. Exodus 1-18. The Anchor Bible. New York: Doubleday, 1999.

Ruggles, D. Fairchild. Gardens, Landscape, and Vision in the Palaces of Islamic Spain. University Park: Penn State University Press, 2000.

Sela, Shlomo. Astrology and Biblical Exegesis in the Thought of Abraham Ibn Ezra.

Ramat Gan: Bar-Ilan University, 1999. [Hebrew]

Shemesh, Abraham O. Medical Materials in Medieval and Modern Jewish Literature:

Pharmacology, History and Halacha. Ramat Gan: Bar Ilan University Press, 2013. [Hebrew]

Shinan, Avigdor. The World of the Aggadic Literature. Tel Aviv: Ministry of Defence, 1987. [Hebrew]

"Dating Targum Pseudo-Jonathan: Some More Comments." Journal of Jewish Studies 61 (1990): 57-61.

Simon, Uriel. The Ear Discerns Words: Studies in Ibn Ezra's Exegetical Methodology. Ramat Gan: Bar Ilan University Press, 2013 [Hebrew]

Torrey, Charles C. "The Cairo Nilometer: Studies in Ibn Taghrī Birdī's Chronicles of Egypt by William Popper.” Speculum 27 (1952): 417-19.

Tosafot Vechilufin: Jerusalem Translation of the Pentateuch (according to Paris Manuscript). Moshe Ginzburger Edition. Berlin: Calvary 1895. [Hebrew]

Translation of Yonatan ben Uziel on the Torah. Moshe Ginzburger Edition. Berlin: Kaloari, 1903. [Hebrew]

Ulmer, Rivka. "The Nile as the Landscape of the Other." Pages 193-207 in Discussing Cultural Influences: Text, Context, and Non-Text in Rabbinic Judaism. Studies in Judaism. Edited by Rivka Ulmer. Lanham: University Press of America, 2007.

Egyptian Cultural Icons in Midrash. Studia Judaica: Forschungen zur Wissenschaft des Judentums 52. Berlin: Walter de Gruyter, 2009.

Urbach, Ephraim E. Ba'ale Hatosafot: Their Generations, Their Works, Their Methods. Jerusalem: Biyalik Institute, 1986. [Hebrew]

Waterson, James. Sacred Swords: Jihad in the Holy Land 1097-1291. London: Frontline Books, 2010.

Wood, Casey A. and Florence M. Fyfe, transl. and eds. The Art of Falconry by Friedrich II of Hohenstaufen. California: Stanford University Press, 1961. Yalkut Shimoni. Jerusalem, 1960 (Facsimile Warsaw, 1878).

Dr. Abraham Ofir Shemesh, senior lecturer at the Israel Heritage Department of the Faculty of Social Sciences and Humanities, Ariel University, Israel. Email: avi0603@013.net.i1. 